\title{
IMPLEMENTASI MANAJEMEN BERBASIS MADRASAH DALAM PENINGKATAN MUTU
}

\author{
Abd. Wahid Tahir \\ Kantor Wilayah Kementerian Agama Sulawesi Selatan \\ Jalan Nuri No. 53 Kota Makassar \\ Email: kanwilsulsel@kemenag.go.id
}

\begin{abstract}
Abstrak:
Implementasi Manajemen madrasah mengandung dua aspek kajian, pertama kajian dalam dataran konsep suatu pendekatan dalam menjalankan usaha khususnya pada segmen pendidikan yang berupaya memaksimalkan daya saing melalui penyempurnaan secara terus-menerus atas produk, manusia, proses, dan lingkungan organisasi atau lembaga, dan kedua kajian mencakup cara penyampaiannya, yang mencakup pada sepuluh karakteristik dari yaitu berfokus pada pelanggan (internal dan eksternal); berobsesi tinggi pada kualitas; menggunakan pendekatan ilmiah; menyempurnakan kualitas secara berkesinambungan; pendidikan dan pelatihan; menerapkan kebebasan yang terkendali; memiliki kesatuan tujuan; serta melibatkan dan memberdayakan pendidik dan peserta didik. Kedua aspek tersebut harus menjadi kesatuan yang utuh sehingga usaha dalam mencapai tujuan dapat diperoleh secara optimal.
\end{abstract}

\begin{abstract}
:
Implementation Madrasah based management contains the meaning of application management in madrasah to improve the quality of education. The main areas in madrasah that can adopt the principles of quality management are: Application of quality management to improve administrative function in managing madrasah; Integrating Madrasah based management in Madrasah curriculum; Using madrasah-based management in the learning process, especially the process of learning in the classroom. The presence of madrasah based management results in a change in conventional management. Improving the quality of education centered on improving the quality of madarsah.
\end{abstract}

\section{Kata kunci: \\ Manajemen Madrasah, Mutu Madrasah}

MADRASAH mempunyai karakter yang sangat spesifik, bukan hanya melaksanakan tugas pendidikan dan pengajaran agama, tetapi juga mempunyai tugas untuk memberikan bimbingan hidup di dalam masyarakat. Madrasah yang membawa fungsi teologis seperti itu, akan paralel dengan kesadaran teologis masyarakat yang dilandasi oleh kebutuhan memperdalam dan mengamalkan ilmu-ilmu agamanya. Oleh karena itu madrasah adalah milik masyarakat dan menyatu dengan nilai-nilai yang telah hidup dan dikembangkan di dalam kebudayaan sebagai milik masyarakat.

Pembinaan pendidikan yang dilakukan oleh Kementerian Agama selama ini masih perlu langkah-langkah penyesuaian yang strategis. Dalam proses peningkatan kualitas sumber daya manusia, pendidikan memegang peran yang sangat penting dan harus merupakan suatu proses yang terintegrasi dengan proses peningkatan kualitas pembinaan madrasah secara keseluruhan. Salah satu peran penting pendidikan 
adalah menyiapkan sumber daya manusia yang berkualitas sesuai dengan perubahan zaman agar tidak terjadi kesenjangan antara realitas dan idealitas (Shaleh, 2008: ix).

Upaya peningkatan kualitas pengelolaan pendidikan pada madrasah, baik mengenai pengembangan kurikulum, peningkatan profesionalitas guru, pemenuhan kebutuhan sarana prasarana maupun pemberdayaan pendidikan, sedang dilakukan dan akan dilakukan secara terus menerus. Lebih lanjut dikatakan bahwa apabila setiap lembaga penyelenggara pendidikan selalu berupaya untuk memberikan jaminan kualitas dan upaya ini secara terus menerus dilakukan maka diharapkan kualitas pendidikan pada madrasah secara keseluruhan di seluruh Indonesia akan terus meningkat (Departemen Agama, 2006: 19). Upaya tersebut merupakan agenda pemerintah melalui Kementerian Agama yang diarahkan agar setiap satuan pendidikan madrasah selalu berupaya untuk memberikan jaminan kualitas kepada pihak-pihak yang berkepentingan, yaitu suatu jaminan agar setiap penyelenggara pendidikan di madrasah sesuai dengan apa yang seharusnya dan sesuai pula dengan harapan masyarakat. Madrasah mempunyai peran penting dalam peningkatan mutu pendidikan dan sumber daya manusia (SDM), sesuai dengan cirinya sebagai lembaga pendidikan agama, secara ideal madrasah berfungsi dalam penyiapan sumber daya manusia yang berkualitas tinggi, baik dalam penguasaan terhadap ilmu pengetahuan dan teknologi (IPTEK) maupun dalam hal karakter, sikap moral, iman dan taqwa (IMTAQ), serta penghayatan dan pengamalan ajaran agama (Al Attas, 2009: 35-74). Secara ideal menurut penulis lembaga pendidikan berfungsi membina dan menyiapkan peserta didik yang berilmu, berteknologi, berketerampilan tinggi dan sekaligus beriman dan beramal saleh.

Pengaruh pendidikan yang berkualitas dapat dilihat dan dirasakan secara langsung dalam perkembangan kehidupan masyarakat, kehidupan kelompok, dan kehidupan setiap individu. Jika bidang lain seperti ekonomi, pertanian, perindustrian berperan menciptakan sarana dan prasarana bagi kepentingan manusia, maka pendidikan berurusan langsung dengan pembentukan manusianya, bahkan menentukan model manusia yang akan dihasilkannya. Pendidikan yang berkualitas juga memberikan kontribusi yang sangat besar terhadap kemajuan suatu bangsa, terutama dalam membangun watak suatu bangsa (Nation Character Building).

\section{KAJIAN TEORI}

\section{Pengertian Manajemen Berbasis Madrasah}

Manajemen diartikan sebagai ketatalaksanaan penggunaan sumber daya secara efektif untuk mencapai sasaran (Depdiknas: 621). Manajemen adalah suatu proses atau kerangka kerja, yang melibatkan bimbingan atau mengarahkan suatu kelompok orang-orang ke arah tujuan-tujuan organisasional atau maksud-maksud yang nyata (Terry dan Rue, 1982: 1). Dari rumusan manajemen di atas, dapat dipahami bahwa manajemen merupakan suatu proses yang berjalan terus pada suatu arah perbaikan dengan melibatkan orang lain untuk pencapaian tujuan. Oleh karena itu, sumber daya (baik sumber daya alam maupun sumber daya manusia) 
perlu diperhatikan pemanfaatannya secara optimal dalam pencapaian suatu tujuan. Berdasar pada batasan manajemen di atas, maka ruang lingkup manajemen memiliki jangkauan yang luas, dan termasuk di dalamnya adalah manajemen pendidikan. Yang dimaksud manajemen pendidikan di sini adalah aktivitas memadukan sumber-sumber pendidikan agar terpusat dalam usaha mencapai tujuan pendidikan yang telah ditentukan. Defenisi ini, sejalan dengan rumusan yang terdapat dalam Encydopedia of the Social Sciences yang dikutip Panglaykim dan Hazil Tanzil bahwa managemen the process, by which the execution of a given purpose is put into operation and supervised (Panglaykim dan Tanzil, 2011: 26).

Pengertian manajemen adalah sebuah proses, pelaksanaan untuk mencapai suatu tujuan tertentu diselenggarakan dan diawasi. Jadi manajemen pendidikan lebih terfokus kepada upaya manajerial yang meliputi planning, organizing, actuating dan controlling. Pengertian ini sama dengan apa yang telah dikemukakan George R. Terry yang telah dikemukakan sebelumnya. Berdasar dari uraian di atas, maka manajemen mencakup kegiatan untuk mencapai tujuan, dan dalam mencapai tujuan tersebut diadakanlah tindakan-tindakan yang telah ditetapkan sebelumnya. Tindakan-tindakan yang ditetapkan tersebut berupa pengetahuan tentang apa yang harus dilakukan, menetapkan cara bagaimana melakukannya, memahami bagaimana harus melakukan dan mengukur efektifitas dari usaha-usaha yang diinginkan. Termasuk perlunya menetapkan dan memelihara suatu kondisi lingkungan yang memberikan responsi ekonomis, sosial politik serta pengendaliannya.

Adapum Manajemen Berbasis Madrasah yaitu pengembangan dari konsep school based management yang bertujuan untuk mendesain ulang pengelolaan madrasah dengan memberikan keleluasaan otonomi kepada kepala madrasah dan meningkatkan partisipasi masyarakat dalam upaya perbaikan kinerja madrasah yang mencakup guru, siswa, komite madrasah, orang tua siswa, dan masyarakat. Manajemen Berbasis Madrasah (MBM) mengubah sistem pengambilan keputusan dengan memindahkan otoritas pengambilan keputusan dan manajemen dari tingkat nasional pada pihak-pihak terkait dengan madrasah di tingkat lokal (local stakeholder) berdasarkan kebijakan nasional. Manajemen Berbasis Madrasah memberikan keuntungan secara langsung kepada stakeholders, pemanfaatan sumber daya, efektif dalam pembinaan siswa, moral guru dan iklim madrasah serta ada perhatian bersama untuk Pengambilan keputusan, pemberdayaan guru, manajemen madrasah, Perencanaan ulang madrasah dan perubahan Perencanaan (Fatah, 2001: 11).

Sedangkan istilah mutu pendidikan Kamus Besar Bahasa Indonesia mengandung arti ukuran baik untuk suatu benda, kadar, taraf atau derajat, untuk kependidikan adalah derajat kecerdasan, kualitas, meningkatkan pendidikkan (Departemen Pendidikan Nasional, 2008: 604). Selanjutnya kata mutu dalam Kamus Ilmiah Populer, berarti kualitas, derajat atau tingkat (Partanto dan al-Barry, 1994: 505). Sejalan dengan itu, Daulat Tampubolon mengartikan mutu sebagai paduan sifatsifat produk, yang menunjukan kemampuannya dalam memenuhi kebutuhan pe- 
langgan langsung atau tidak langsung baik kebutuhan yang dinyatakan maupun yang tersirat, masa kini dan masa depan (Tampubolon, 2011: 108).

Secara sepintas kata mutu bukanlah kata atau ucapan yang sulit dipahami, karena istilah ini sudah menjadi bahasa sehari-hari, bahwa sesuatu yang bermutu berarti sesuatu yang menyenangkan atau memuaskan bagi seseorang yang mendapatkan sesuatu yang bermutu itu, kendati masih banyak orang yang belum mengetahui bagaimana cara membuat sesuatu itu menjadi bermutu, sehingga seseorang dapat memperoleh kepuasan yang optimal. Tampubolon mengemukakan bahwa bagi setiap institusi, mutu adalah agenda utama dan meningkatkan mutu merupakan tugas paling penting. Institusi pendidikan, baik milik pemerintah maupun milik swasta telah banyak mengetahui mutu dan memahami rahasia memperoleh mutu, karena mereka menyadari bahwa meraih sumber-sumber mutu adalah sebuah keharusan. Adapun sumber-sumber mutu dalam pendidikan antara lain; sarana gedung yang bagus, guru yang professional, nilai moral yang tinggi, hasil ujian yang memuaskan, spesialisasi atau kejuruan, dorongan orang tua, sumber daya yang melimpah, aplikasi teknologi mutakhir, kepemimpinan yang baik dan efektif, kurikulum yang memadai dan perhatian terhadap peserta didik, dan sebagainya (Tampubolon, 2011:30).

Berdasakan dari uraian di atas, dapat dipahami bahwa yang dimaksud penulis implementasi Manajemen Berbasis Madrasah dalam upaya meningkatkan mutu pendidikan adalah suatu sistem implementasi dalam menjalankan suatu usaha pendidikan yang berusaha memaksimumkan daya saing melalui penyempurnaan terus menerus dalam meningkatkan kualitas pendidikan secara totalitas.

\section{Implementasi Manajemen Berbasis Madrasah dalam Peningkatan Mutu}

Dalam kerangka perwujudan implementasi manajemen di madrasah dalam meningkatkan mutu pendidikan dan kualitas SDM tersebut, sistem pendidikan haruslah senantiasa mengorientasikan diri untuk menjawab kebutuhan dan tantangan yang muncul dalam masyarakat sebagai konsekwensi logis dari perubahan. Pembangunan yang berlangsung demikian cepat dalam beberapa dasawarsa terakhir telah mengantarkan Indonesia ke dalam barisan Negara-negara yang disebut NICS (New Industrialized Countries) atau negara-negara industri baru. Meski Indonesia telah mencapai kemajuan seperti itu, pembangunan tentu saja masih jauh dari pada selesai. Bahkan sebaliknya, Indonesia harus semakin meningkatkan momentum pembangunannya (Nata, 2008: 1). Untuk itu, tidak ada alternatif lain, kecuali penyiapan SDM yang berkualitas tinggi, menguasai ilmu pengetahuan dan teknologi, serta keahlian dan keterampilan. Hanya dengan tersedianya SDM yang berkualitas tinggi itu, Indonesia bisa survive di tengah pertarungan ekonomi politik Internasional sesuai dengan UndangUndang RI No. 20 tahun 2003 tentang pendidikan nasional.

Perhatian manajemen pada peningkatan mutu suatu produk dalam dasawarsa ini terus meningkat pesat. Perkembangan dimulai dari dunia industri dan dianggap berhasil dalam meningkatkan efisiensi dan penjualan produksi dunia industri tersebut. Keberhasilan itu, merambah ke setiap kegiatan yang menggunakan manajemen untuk meningkatkan kinerja organisasi (Mantja, 2010: 10). tidak ketinggalan juga pa- 
da dunia pendidikan. Manajemen peningkatan mutu pada Madrasah merupakan salah satu pola manajerial dalam upaya merespon masyarakat yang cepat dan terus menerus (Mantja, 2010: 11).

Implementasi Manajemen Berbasis Madrasah dalam upaya meningkatkan mutu pendidikan memang belum banyak dilakukan, bahkan ada sementara kalangan yang meragukan efektifitas Manajemen Berbasis Madrasah dalam dunia pendidikan. Sementara kalangan yang lain menganggap Manajemen Berbasis Madrasah sebagai suatu harapan yang cerah bagi dunia pendidikan. Aplikasi manajemen berbasis madrasah mengundang perdebatan. Beberapa pakar pendidikan mempertanyakan kelayakan dan kesesuaian konsep Manajemen Berbasis Madrasah dengan karakteristik madrasah. Pengamat tersebut berargumen bahwa Manajemen Berbasis Madrasah dalam peningkatan mutu merupakan konsep yang sulit untuk dievaluasi dalam dunia pendidikan khususnya di Madrasah (Kotler, 1997: 38).

Menurut Wina Sanjaya ada empat bidang utama dalam madrasah yang dapat mengadopsi prinsip-prinsip manajemen mutu yaitu:

1. Penerapan manajemen mutu untuk peningkatan fungsi administrasi dan operasi secara luas untuk mengelola madrasah secara keseluruhan. Implementasi konsep Manajemen Mutu khususnya pada madrasah dalam meningkatkan fungsi administrasi, dimaksudkan untuk memberi penguatan terhadap manajemen peningkatan mutu yang selama ini telah dilakukan oleh madrasah, seperti Manajemen Berbasis Madrasah (MBM) atau Manajemen Peningkatan Mutu Berbasis Sekolah/Madrasah (MPMBS/M), yang oleh sebahagian pakar manajemen pendidikan menyatakan bahwa dasar dari manajemen ini dikembangkan dari konsep manajemen mutu terpadu, yang pada mulanya diterapkan pada dunia bisnis. Fungsifungsi Manajemen pada Madrasah merupakan faktor penting dan strategis dalam rangka kemajuan Madrasah sebagai suatu lembaga pendidikan formal yang diharapkan dapat mencapai tujuan institusionalnya yang memiliki sumber daya manusia (SDM) yang memadai dan dikelolah dengan sistem administrasi dan manajemen pendidikan yang sehat yakni suatu system manajemen yang menerapkan fungsi-fungsi manajemen yaitu perencanaan, pengorganisasian, pelaksanaan, pengawasan dan penilaian. Madrasah sebagai wadah untuk mencerdaskan kehidupan bangsa yang merupakan amanah Allah dan amanah Undang-Undang Dasar 1945 melalui pendidikan madrasah sebagai lembaga pendidikan formal yang mengaplikasikan fungsi-fungsi manajemen dalam kegiatan pengelolaannya (Sanjaya, 2009: 243).

2. Mengintegrasikan Manajemen Berbasis Madrasah dalam kurikulum, fungsi kurikulum dalam rangka pencapaian tujuan pendidikan, kurikulum dapat dipandang sebagai alat untuk pencapaian tujuan pedidikan nasional, dengan menjabarkannya secara berturut menjadi tujuan nasional, tujuan kurikuler dan tujuan instruksional, pada setiap jenis dan jenjang lembaga pendidikan (madrasah). Kurikulum dalam peningkatan mutu merupakan program pendidikan yang harus diikuti oleh peserta didik atas bimbingan para pendidik untuk mencapai tujuan 
pendidikan serta sebagai pedoman bagi guru dan peserta didik dalam pelaksanaan prosespembelajaran, agar tujuan pendidikan yang telah ditetapkan benar-benar tercapai. Jenis pengetahuan/keahlian, sikap dan keterampilan yang dimiliki oleh lulusan suatu madrasah dapat diketahui melalui kurikulum madrasah tersebut. Kurikulum merupakan salah satu komponen yang sangat menentukan dalam suatu sistem pendidikan, karena ia merupakan alat untuk mencapai tujuan pendidikan dan sekaligus sebagai pedoman dalam pelaksanaan pengajaran pada semua jenis dan tingkat pendidikan. Tujuan pendidikan di suatu bangsa ditentukan oleh falsafah dan pandangan hidup bangsa atau negara tersebut. Berbedanya falsafah dan pandangan hidup suatu bangsa atau negara menyebabkan berbeda pula tujuan yang hendak dicapai dalam pendidikan tersebut, dan sekaligus akan berpengaruh pula terhadap kurikulum di lembaga-lembaga pendidikan yang ada dalam negara tersebut (Ramayulis, 2008: 65). Begitu pula perubahan politik pemerintahan suatu negara mempengaruhi pula bidang pendidikan, yang sering membawa akibat terjadinya perubahan kurikulum yang berlaku. Oleh karena itu, kurikulum perlu diintegrasikan dengan manajemen mutu guna menyesuaikan dengan berbagai perkembangan yang terjadi.

3. Implementasi Manajemen Berbasis Madrasah dalam proses pembelajaran. Penggunaan Manajemen Berbasis Madrasah dalam proses pembelajaran, guru merupakan pendidik yang sangat mempengaruhi kepdibadian peserta didik. Misalnya, apabila tingkah laku pendidik atau guru itu baik, maka tingkah laku peserta didik juga mayoritas baik. Demikian pula sebaliknya, jika sikap atau akhlak pendidik kurang baik, maka jelas pula bahwa sikap atau akhlak peserta didiknya akan kurang baik juga. Karena sikap peserta didik mudah meniru segala tingkah dan perbuatan oleh orang yang disenanginya termasuk guru yang merupakan sosok teladan bagi mereka. Kehadiran guru di madrasah dan masyarakat merupakan faktor utama dalam mencapai tujuan pendidikan dalam peningkatan mutu dan layanan. Keterampilan seorang guru di dalam merencanakan dan melaksanakan proses pembelajaran merupakan sesuatu yang erat kaitannya dengan tugas dan tanggung jawab guru sebagai pengajar yang mendidik di madrasah dan juga lingkungan masyarakat. Guru sebagai pendidik mengandung arti yang sangat luas, tidak sebatas memberikan bahan-bahan pengajaran tetapi menjangkau etika dan estetika serta pengunaan manajemen berbasis madrasah dalam menghadapi tantangan kehidupan di masyarakat (Arifin, 2009: 88). Guru sebagai pendidik harus selalu cermat dalam menentukan langkah serta tanggap terhadap situasi dan kondisi. Oleh karena itu, kompetensi merupakan bagian integral yang tidak dapat dipisahkan dari diri seseorang dalam melaksanakan sebuah tugas. Maka dapat dipahami bahwa kompetensi seorang guru merupakan suatu komponen yang harus dimiliki atau dikuasai oleh seorang guru dan sebagai alat untuk memberikan bantuan dan pelayanan terbaik kepada peserta didik dalam proses pembelajaran di kelas. 
3. Implementasi Manajemen Berbasis Madrasah untuk mengelola aktifitas evaluasi madrasah. Evaluasi Madrasah merupakan proses yang sangat penting dalam kegiatan pendidikan formal. Evaluasi dapat menentukan evektifitas kinerja selama ini, evaluasi sering dianggap sebagai salah satu hal yang menentukan bagi pengelolaan madrasahl dan menentukan kualitas peserta didik. Karena, melalui kegiatan evaluasi dapat ditentukan orientasi dalam proses pengelolaan selanjutnya. Evaluasi mestinya dipandang sebagai sesuatu yang wajar yakni sebagai suatu bagian integral dari suatu proses kegiatan pembelajaran (Sanjaya, 2009: 246).

Kehadiran Manajemen Berbasis Madrasah berdampak pada perubahan manajemen konvensional. Demikian halnya dengan manajemen pada lembaga pendidikan. Terdapat tantangan pokok yang dikaji dan dikelola secara strategis dalam rangka menerapkan konsep manajemen berbasis madrasah dalam meningkatkan mutu pendidikan pada madrasah yakni berkenaan dengan dimensi kualitas fokus pada pelanggan, kepemimpinan, perbaikan berkesinambungan, manajemen SDM, dan manajemen berdasarkan fakta.

Tantangan yang dihadapai oleh madrasah baik tantangan dari dalam (internal challenges), maupun tantangan dari luar (external challenges) yang semakin kompleks, sehingga menuntut perlunya ada upaya peningkatan mutu pendidikan yang merupakan salah satu prasyarat dalam memasuki era globalisasi. Secara khusus keberadaan madrasah sebagai salah satu lembaga pendidikan Islam tidak lepas dari prasyarat tersebut. Untuk itu peningkatan kualitas merupakan agenda utama dalam meningkatkan mutu madrasah agar dapat survive dalam era global. Dengan demikian, di era persaingan global seperti sekarang ini, sudah saatnya institusi pendidikan Islam dikembangkan dengan menggunakan pola manajemen berbasis industry (Siagian, 2009: 18). Pengelolaan model ini menuntut adanya upaya pihak pengelola institusi pendidikan untuk meningkatkan mutu pendidikan dengan berbagai pendekatan seperti pendekatan manajemen mutu.

Manajemen mutu adalah sebuah sistem pendekatan dalam upaya memaksimalkan daya saing melalui perbaikan secara berkesinambungan (terus menerus) untuk memperoleh nilai atau mutu yang optimal atas jasa, manusia, produk dan lingkungan dengan melibatkan keseluruhan unsur dan stakeholders organisasi di bawah satu visi bersama (Makbuloh, 2011: 4). Salah satu masalah penting di dalam dunia pendidikan adalah masih rendahnya mutu keluarannya. Indikator yang menjadi acuan untuk menguatkan pernyataan tersebut adalah Nilai Ujian Nasional yang secara umum belum terlalu menggembirakan, artinya batas minimal kelulusan masih rendah dibandingkan negara tetangga. Upaya meningkatkan mutu pendidikan telah lama diprogramkan oleh pemerintah dengan merumuskan misi pendidikan nasional sebagai strategi pembangunan di bidang pendidikan sebagai berikut;

1. Perluasan kesempatan dan pemerataan memperoleh pendidikan yang bermutu bagi seluruh rakyat Indonesia.

2. Meningkatkan mutu pendidikan yang memiliki daya saing di tingkat nasional, regional dan internasional. 
3. Meningkatan relevansi pendidikan dengan kebutuhan masyarakat dan tantangan global.

4. Membantu dan menfasilitasi pengembangan potensi anak bangsa secara utuh sejak usia dini sampai akhir hayat dalam rangka mewujudkan masyarakat belajar.

5. Meningkatkan kesiapan masukan dan kualitas proses pendidikan untuk mengoptimalkan pembentukan kepribadian yang bermoral.

6. Meningkatkan keprofesionalan dan akuntabilitas lembaga pendidikan sebagai pusat pembudayaan ilmu pengetahuan, keterampilan, pengalaman, sikap dan nilai berdasarkan standar yang bersifat nasional dan global.

7. Mendorong peran serta masyarakat dalam penyelenggaraan pendidikan berdasarkan prinsip otonomi dalam konteks Negara Kesatuan Republik Indonesia (Departemen Agama RI, 2006: 196).

Peningkatan mutu pendidikan yang berpusat pada peningkatan mutu madrasah merupakan suatu proses yang dinamis, berjangka panjang yang musti dilakukan secara sistematis dan konsisten untuk diarahkan menuju suatu tujuan tertentu. Peningkatan mutu sekolah/madrasah tidak bersifat instan, melainkan suatu proses yang harus dilalui dengan sabar, tahap demi tahap, yang terukur dengan arah yang jelas dan pasti. Dalam peningkatan mutu sekolah atau madrasah tidak semudah membalik telapak tangan atau bukan sesuatu yang gampang segampang teori, namun tidak mungkin ada peningkatan mutu sekolah tanpa didasari oleh suatu teori dan sistem manajemen yang efektif. Peningkatan mutu madrasah memerlukan teori, namun implementasinya tidak akan bisa mulus dan semudah teori yang ada. Sebab peningkatan mutu bersifat dinamis yang amat terkait dengan berbagai faktor atau variabel (Pontjorini, dkk., 2006: 97). Peningkatan mutu dalam proses pembelajaran sangat terkait dengan interaksi antara peserta didik dan pendidik berkaitan dengan materi tertentu, maka tidak hanya kondisi peserta didik yang berpengaruh, tetapi juga kondisi pendidik tidak kalah pentingnya mempengaruhi kualitas pembelajaran. Pendidik adalah mediator yang bisa memberi pengalaman mendasar yang memungkinkan peserta didik menunjukkan potensi yang luar biasa yang dimilikinya (Arcaro, 2007: 65). Kualitas interaksi juga dipengaruhi oleh keberadaan dan kualitas fasilitas, termasuk kurikulum yang dipergunakan dan manajemen madrasah yang dijalankan oleh kepala madrasah. Mutu produk pendidikan akan dipengaruhi oleh sejauh mana lembaga mampu mengelola seluruh potensi secara optimal mulai dari tenaga kependidikan, peserta didik, proses pembelajaran, sarana pendidikan, keuangan dan termasuk hubungannya dengan masyarakat. Pada kesempatan ini, lembaga pendidikan Islam harus mampu merubah paradigma baru pendidikan yang berorientasi pada mutu semua aktifitas yang berinteraksi di dalamnya, seluruhnya mengarah pencapaian pada mutu. Menurut Poerwanegara peningkatan mutu meliputi enam unsur dasar yang mempengaruhi suatu produk yakni 1) Manusia 2) Metode 3) Mesin 4) Bahan 5) Ukuran dan 6) Evaluasi Berkelanjutan. Demikian juga dalam pendidikan, bahwa keenam hal tersebut cocok untuk dijadikan pedoman dalam menyusun manajemen, khususnya administrasi pendidikan. (Poerwanegara, 2002: 12). 
Beranjak dari pembahasan tersebut, dalam operasi Manajemen Berbasis Madrasah dalam pendidikan ada beberapa hal pokok yang perlu diperhatikan:

1. Perbaikan secara terus menerus (Continuous Improvement). Konsep ini mengandung pengertian bahwa pihak pengelola senantiasa melakukan berbagai perbaikan dan peningkatan secara terus menerus untuk menjamin semua komponen penyelenggara pendidikan telah mencapai standar mutu yang diterapkan.

2. Menentukan standar mutu (Quality Assurance). Paham ini digunakan untuk menetapkan standar-standar mutu dari semua komponen yang bekerja dalam proses produksi atau transformasi lulusan institusi pendidikan.

3. Perubahan kultur (Change of Culture) Konsep ini bertujuan membentuk budaya organisasi yang menghargai mutu dan menjadikan mutu sebagai orientasi semua komponen organisasional.

4. Perubahan organisasi (Upside-Down Organization) Jika visi dan misi, serta tujuan organisasi sudah berubah atau mengalami perkembangan, maka sangat dimungkinkan terjadinya perubahan organisasi. Perubahan organisasi ini bukan berarti perubahan wadah organisasi, melainkan sistem atau struktur organisasi yang melambangkan hubungan-hubungan kerja dan kepegawaian dalam organisasi, yang menyangkut perubahan kewenangan, tugas-tugas dan tanggung jawab.

Mempertahankan hubungan dengan pelanggan (Keeping Close to The Customer) Karena organisasi pendidikan menghendaki kepuasan pelanggan, maka perlunya mempertahankan hubungan baik dengan pelanggan menjadi sangat penting. Inilah yang dikembangkan dalam unit public relation.

\section{DAFTAR PUSTAKA:}

Arcaro, J. S. (2007). Pendidikan Berbasis Mutu, Prinsip-prinsip Perumusan dan Tata Langkah Penerapan. Cet. IV: Yogyakarta; Pustaka Pelajar.

Arifin, M. (2009). Kapita Selekta Pendidikan Islam. Jakarta: Bulan Bintang.

Al-Attas, S. M. N. (2009). Konsep Pendidikan dalam Islam: Suatu Rangka Pikir Pembimbing Filsafat Pendidikan Islam, Cet. I; Bandung: Mizan.

Departemen Pendidikan Nasional. (2008). Kamus Besar Bahasa Indonesia. Jakarta: Balai Pustaka.

Depatemen Agama. (2006). Profil Madrasah Masa Depan, Cet. I; Jakarta: Direktorat Jenderal Pendidikan Islam.

Fatah, N. (2001). Landasan Manajemen Pendidikan. Bandung: Remaja Rosdakarya.

Kotler, P. (1997). Marketing Management, Alih bahasa, Hendra Teguh, Ronny A. Rusli, Agus Hasan Pura Anggawijaya dengan judul: Manajemen Pemasaran: Analisis, Perencanaan, Implementasi, dan Kontrol. Jakarta: Kosasih Iskandariyah.

Makbuloh, D. (2011). Manajemen Mutu Pendidikan Islam, Model pengembangan Teori dan Aplikasi Sistem Penjaminan Mutu, Cet. I; Jakarta: PT. Rajagrafindo Persada.

Mantja, W. (2010). Manajemen Peningkatan Mutu Pendidikan, Cet. I; Jakarta: LIPI.

Nata, A. (2008). Manajemen Pendidikan Mengatasi Kelemahan Pendidikan Islam di Indonesia, Cet. I; Jakarta: Kencana Prenada Media Group.

Panglaykim \& Hazil, T. (2011). Manajemen Suatu Pengantar, Cet. XV; Jakarta: Ghalia Indonesia. 
Partanto, P. A., \& Dahlan, M. (1994). Kamus llmiah Poputer, Surabaya: Arkola.

Poerwanegara, S. (2002). Filosofi Baru Tentang Manajemen Mutu Terpadu, Cet. I; Jakarta: PT. Bumi Aksara.

Pontjorini, E. R., dkk. (2006). Sistem Informasi Manajemen Pendidikan, Cet.I; Jakarta: Bumi Aksara.

Ramayulis. (2008). Ilmu Pendidikan Islam, Cet. II; Jakarta: Kalam Mulia.

Salindeho, J. (2009). Peranan Tindak Lanjut dalam Manajemen, Cet. II; Jakarta: Sinar Grafika.

Sanjaya, W. (2009). Perencanaan dan Desain Sistem Pembelajaran, Cet.I; Jakarta: Kencana.

Shaleh, A. R. (2008). Penyelenggaraan Madrasah. Jakarta: Dharma Bakti.

Siagian, S. P. (2009). Filsafat Administrasi, Cet. I; Jakarta: Gunung Agung.

Tampubolon, D. P. (2011). Perguruan Tinggi Bermutu: Paradigma Baru Manajemen Pendidikan Tinggi Menghadapi Abad ke-21, Cet. I; Jakarta: PT. Gramedia Pustaka Utama.

Terry, G. R., \& L.W. Rue. (1982). Principle of Management, New York, Dow Jones-Irwin. 